\title{
DIGITAL TECHNOLOGY IN BANKING POST DEMONETIZATION
}

\author{
Dr. Itikela Shyam Sundar ${ }^{* 1}$ 四 \\ ${ }^{* 1}$ Associate Professor, Nigama Engineering College, Karimnagar, Telangana, India
}

DOI: https://doi.org/10.29121/ijetmr.v7.i7.2020.711

Article Citation: Dr. Itikela Shyam Sundar. (2020). DIGITAL TECHNOLOGY IN BANKING POST DEMONETIZATION. International Journal of Engineering Technologies and Management Research, 7(7), 814. https://doi.org/10.29121/ijetmr.v7 i7 7.2020 .711

Published Date: 7 July 2020

\section{Keywords:}

Demonetization

Digital Payments

Adoption Behaviour

\section{ABSTRACT}

This research investigates the differences in the technology adoption behaviour of customers of Indian banks during the pre and post demonetization phase. The Survey results of 200 bank customers in India find that the Indians are still holding back from embracing the digital platforms to make payments. The study could not establish the constructive effects of demonetization in e-banking adoption behaviour, despite the significant growth in the use of small digital payment platforms like Paytm. However, the usage of Point of Sale (POS) machines for transacting payments has increased tremendously. The research finds drastic reductions in the use of other e-payment modes during and after demonetization. In that sense, the study concludes that the demonetization negatively affects the technology banking adoption behaviour of customers of Indian banks.

\section{INTRODUCTION}

Demonetization is the act of stripping a currency unit of its status as legal tender, and in some cases replacing it with new currency units (Litvack and Vigne (2017). The Government of India implemented this policy on 8th November 2016 and removing 500 rupees and 1000 rupees notes from its status of legal tender. The movement was a big shock to the residents of India earlier, although they had no more than a temporary effect on the economy as lending continued to flow. Initially, the Government of India was on the argument that the demonetization is an endeavour to stop counterfeiting notes of the current banknotes allegedly used for funding terrorism, as well as a crackdown on black money in the country. The Government described the move as an effort to trim down the corruption, controls the use of drugs and smuggling. However, later the Government has been claimed or still claiming that the demonetization is proven a catalyst for consumption to be digitally driven and payments to go cashless. Even though this came as a panic situation, through this, the digital payment systems attracted more people into its usage.

Demonetization has not only contributed towards the curbing of black money, but also to the expansion of the e- banking industry. It pushed millions of new users into the country's digital economic grid. In other sense, demonetization exactly intends to create a digitalized economy. At this stage, it is fundamental to make out, to what extent the people in an economy are ready to adapt to the new digitalized economic system and also to analyse their attitude and behaviour towards the innovative mode of payment systems. This research compares the awareness and usage pattern of digital payment services among the public during the pre and post demonetization to determine how far the demonetization policy of the government brings change in the banking technology adoption behaviour

(C) 2020 The Author(s). This is an open access article distributed under the terms of the Creative Commons Attribution License, which permits unrestricted use, distribution, and reproduction in any medium, provided the original author and source are credited. 
of people in India. In short, this study analyses the impact of demonetization on the digital adoption behaviour of people in India.

Indian people are more reliant on cash than almost any other country on earth. The people involved in the electronic banking system are also less. Demonetization brought many people into the e-banking system. The research problem is that how the people in the e-banking system before demonetization differ from those people after demonetization in the e-banking system. The solution to the problem can be found by comparing the usage of e-banking services both before and after the demonetization phase.

We proceed to the remainder of the paper as follows. The next Section reviews the empirical literature on the problem that we investigate through this research. While Section 3 outlines data and methodology, Section 4 discusses the empirical results of the research before we finally conclude the research in Section 5.

\section{EMPIRICAL LITERATURE}

Electronic banking is an innovation powered by merging new information technologies into traditional banking services. Hyde (2015) asserts empirical literature on e-banking research that has happened in different market contexts. Cost efficiency and revenue optimizations are the forces that mainly promote digital banking services (Reibstein, 2002). Digital banking payment system reduces bankers' intervention and promote self-service by customers (Witman and Poust, 2008). The effects of e-banking can be revealed in the form of the growth in assets, reduction in operating costs (Dandapani et al., 2008). Jenkins (2007) shows that the banks which, are using ebanking often find it as a guarantee of competitive customer service delivery. Customers will be attracted to ebanking when the add on e-banking services like e transfer and e-bill options are available (Amato-McCoy 2005). Zafar et al. (2011) commented that if customers find themselves satisfied with online banking services, they will be inclined to adopt electronic banking. The improving perceptions of trust (safety, security, and credibility), usefulness and ease of use of e-banking systems would result in increased adoption of e-banking system (Mwyia et al. 2017). Abbasi et al. (2017) observe that access to the internet, ease of use and security and privacy are found to be critical factors influencing the adoption of internet banking. There is no significant variance in consumer perception based on the demographic factors such as gender, age, profession and annual income of the patients (Singh, 2017). However, education was found to significantly influence the adoption of digital payment.

The demonetization policy by the Government is a large shock to the economy and the impact of the shock in the medium term is a function of how much of the currency will be replaced at the end of the replacement process and the extent to which currency in circulation is extinguished (Rao et al. 2016). Kaur (2017) observed that the cashless transaction system is reaching its growth day by day, as both the market become globalized and the growth of banking sector is moving more and more people from cash to cashless system. The introduction of 3G and 4G network has enabled more and more people to go for internet banking for banking facilities (Dhir 2017). The demonetization exercise indirectly helped in modifying the public's financial well-being by promoting digital payments, creating an integrated form of financial inclusion in India (Srikrishnan, 2017).

The increasing use of digital payment modes in India is bringing in many changes in the Indian retail sector. The choice of payment mode by the consumer after demonetization has brought drastic changes in the economic landscape. Only very few research investigating the effects of demonetization in e-payment behavior in India context came out. Moreover, the studies exploring this issue in the Telangana context have yet to come out. Hence, there exists a scope for further research for identifying the impact of demonetization on digital payments in India.

\section{EMPIRICAL METHODOLOGY}

The research is descriptive and the primary data provides needed inputs for analysis. Based on the nature of the research, the study has made formal quantitative as well as qualitative data collection administering a survey through distributing interview schedules among the people belonging to the various age categories in various parts of India. The sample for this study covers 200 respondents. The personal judgment of the researcher forms the basis for sample selection.

The theoretical underpinnings and the related empirical literature enable the current research to develop a conceptual framework. The questions in the questionnaire compare the answers to the questions on awareness, usage, level of usage, the period of usage, and the reasons for the adoption of e-banking services during the pre and 
demonetization phase. The research measures the underlying variables explaining each of these behavioral components separately using appropriates scaling techniques.

The study uses data of both categorical and scale form. Five-point Likert type scaling is used to measure data. The study mainly uses simple tools, count and frequencies for the data analysis. For making statistical inferences about peoples' perception of the impact of demonetization on the general economy and its influence in the adoption of e-banking behaviour, one sample parametric form of t-test has been applied.

Table 1: Descriptive of the Sample Respondents

\begin{tabular}{|l|c|c|c|}
\hline Demographic Variable & Category & No of respondents & $\%$ \\
\hline \multirow{4}{*}{ Eender } & Male & 102 & 51.0 \\
\cline { 2 - 4 } & Female & 98 & 49.0 \\
\hline \multirow{4}{*}{ Monthly Income (Rs.) } & Upto Graduation & 98 & 49.0 \\
\cline { 2 - 4 } & PG & 46 & 23.0 \\
\cline { 2 - 4 } & Others & 56 & 28.0 \\
\cline { 2 - 4 } & Below 25000 & 52 & 26.0 \\
\cline { 2 - 4 } Age (Years) & $25000-50000$ & 91 & 45.5 \\
\cline { 2 - 4 } & $50000-75000$ & 38 & 19.0 \\
\hline \multirow{4}{*}{ Employment status } & 75000 \& Above & 19 & 9.5 \\
\cline { 2 - 4 } & Upto 25 & 46 & 23.0 \\
\cline { 2 - 4 } & $25-50$ & 94 & 47.0 \\
\cline { 2 - 4 } & Above 50 & 60 & 30.0 \\
\cline { 2 - 4 } & Employed & 138 & 69.0 \\
\cline { 2 - 4 } & Business & 28 & 14.0 \\
\cline { 2 - 4 } & Profession & 22 & 11.0 \\
\hline
\end{tabular}

Source: survey data

Some descriptive statistics relative to the sampled customers are reported in Table 1 . The representation of male and female customers is almost equal. (Table1). The survey has been conducted among an educated group where most of the customers gained University education. Somewhat customers up to Graduation constitute a large chunk of the participants. Most of the students belong to the age group of 25 to 50 years, although representation from other age groups is also significant in number. Furthermore, the survey is conducted among persons with different occupational status. However, more than two-third portion of the sample consists of employees and businesspersons and professionals are almost equal in number. The income conditions of the customers are at least at a moderate level as only 26 percent of the customers lies in the monthly income range of less than Rs. 25,000. Thus, the survey is conducted mainly among a gender-independent middle-aged and educated employees class with a decent monthly income of about Rs. 50,000 per month.

\section{RESULTS AND DISCUSSIONS}

This part discusses the results of the analytical methodology pursued along with its practical implications in assessing the e-banking behaviour of people in Telangana. At first, we compute Cronbach's alpha for testing the reliability of the scale used in the research. The computed Cronbach's alpha coefficient of 0.768 indicates the scale used to measure the perception of customers is highly reliable. Further discussions are spanned into two sections. The first section compares the customers' usage patterns of different e-banking services and the reasons raised by them for embracing digital payments or e-banking services are corroborated in the second section.

In this research on the digital banking technology adoption behavior of 200 respondents, both incremental and decremental changes had occurred in their usage of various e-banking services when they are compared in pre and post demonetization phases.

ATMs show a decremental change of 21 percent as there was a shortage of currencies that could be withdrawn. No change in Internet banking is found in this research and its usage is similar in both pre and post demonetization 
phases. The usage of mobile banking is shown an increase of 5.45 percent, while both the debit and credit cards show a decrement of about 29 percent. The usage of a smart card is decreased by 40 percent. Similarly, the transfer of funds electronically is decreased marginally. The usage of point of sale machines is increased by more than 20 percent. Rupay card is registered a decremental change of 16.67 percent. The

Immediate Payment Service has also decreased by 33.33 percent. Paytm is the one that has shown an amazing increase in usage. It has found more than 70 percent usage than before (Table 2).

Table 2: Distribution of samples based on the usage of various e-banking services before and after demonetization

\begin{tabular}{|c|c|c|c|c|c|}
\hline \multirow[t]{2}{*}{ E-banking sevices } & \multicolumn{2}{|c|}{ Pre-demonetization } & \multicolumn{2}{|c|}{ Post-Demonetization } & \multirow{2}{*}{$\begin{array}{c}\text { Incremental/ Decremental } \\
\text { Usage (\%) }\end{array}$} \\
\hline & Used (\%) & Not Used (\%) & Used (\%) & Not Used (\%) & \\
\hline ATMs & 99 & 1 & 78 & 22 & -21 \\
\hline Internet Banking & 64 & 36 & 64 & 36 & 0 \\
\hline Mobile Banking & 55 & 45 & 58 & 42 & 5.45 \\
\hline Debit Card & 51 & 49 & 36 & 64 & -29.41 \\
\hline Credit Card & 28 & 72 & 20 & 80 & -28.57 \\
\hline Smart Card & 5 & 95 & 3 & 97 & -40 \\
\hline EFT & 41 & 59 & 40 & 60 & -2.43 \\
\hline Point of sale & 34 & 66 & 41 & 50 & 20.58 \\
\hline Rupay Card & 6 & 94 & 5 & 95 & -16.67 \\
\hline IMPS & 10 & 90 & 7 & 93 & -33.33 \\
\hline Paytm & 21 & 79 & 36 & 64 & 71.42 \\
\hline
\end{tabular}

Source: Survey data

The main goals of demonetization, according to Government sources, is making our economy cashless and curbing black money. How far they said demonetization policy is effective in meeting these goals, a question is asked to respondents and their perceptions are quantified on a five-point scale. Then the mean score is computed and we test the statistical significance of the same under the parametric test procedure and the results of which are reported in Table 3. On interpreting the results, it comes to know that the people perceived the impact of demonetization as ineffective in meeting its prime goal as the mean score is less than the median score of 3 . Again, according to the ttest, it is statistically validated as the mean scores of 2.29 and 2.31 are significantly lower than 3 . Hence, we can say that the demonetization policy is neither effective in curbing black money nor successful in making our economy cashless.

Table 3: Effectiveness of Demonetization in Bringing its Goals into Reality: Inferential Analysis

\begin{tabular}{|l|l|l|l|}
\hline \multicolumn{1}{|c|}{ Variable } & Mean & t statistic & P value \\
\hline Effectiveness of making our economy cashless & 2.29 & -7.342 & $0.000^{*}$ \\
\hline Effectiveness of demonetization policy of the Government in curbing black money & 2.31 & -7.261 & $0.000^{*}$ \\
\hline
\end{tabular}

Sources: Computed from Survey Data *Significant at $1 \%$ level

Table 4: Major Uses of E-banking Services after Demonetization: Mean Score Analysis

\begin{tabular}{|l|c|c|}
\hline \multicolumn{1}{|c|}{ Variable } & Mean & Rank \\
\hline Cash Withdrawal & 1.28 & 1 \\
\hline Depositing Cash & 1.94 & 2 \\
\hline Checking Account Balance & 2.35 & 4 \\
\hline Paying Utility Bills & 2.36 & 5 \\
\hline Transfer of Funds & 2.17 & 3 \\
\hline Purchase at POS & 2.61 & 6 \\
\hline
\end{tabular}

Sources: Computed from Survey Data 


\section{Dr. Itikela Shyam Sundar}

On analysing the Table 4, it is revealed that during the times of demonetization people predominantly depend on e-banking platform for making a purchase at POS followed by paying utility bills and checking account balances. It is also right to say that demonetization brought cash withdrawal most difficult because of either shortage of cash or non-availability of currencies in needed denominations.

Table 5: Reasons for the Adoption of E-banking services during Demonetization Phase: Inferential Analysis

\begin{tabular}{|l|c|c|c|}
\hline \multicolumn{1}{|c|}{ Variable } & Mean & t statistic & P value \\
\hline $\begin{array}{l}\text { Adoption of e-banking services due to the } \\
\text { shortage of liquid cash. }\end{array}$ & 3.58 & 5.175 & $0.000^{*}$ \\
\hline $\begin{array}{l}\text { Adoption due to more awareness of the benefits } \\
\text { of e-banking services in the demonetization phase. }\end{array}$ & 4.05 & 13.189 & $0.000^{*}$ \\
\hline $\begin{array}{l}\text { Adoption for supporting Government's policy to } \\
\text { curb black money }\end{array}$ & 3.97 & 9.514 & $0.000^{*}$ \\
\hline $\begin{array}{l}\text { Adoption as using e-banking services will be a } \\
\text { self-contribution to have a cashless economy }\end{array}$ & 3.90 & 10.205 & $0.000^{*}$ \\
\hline
\end{tabular}

Sources: Computed from Survey Data $\quad *$ Significant at $1 \%$ level

Even though the peoples' perception of the effectiveness of demonetization is negative, they have partially inclined to the adoption of e-banking products in their lives. Here also, Likert type scaling measures their opinion as to the reasons why they adopt e-banking services in their daily lives. Mean score analysis revealed that better awareness of e-banking services during the times of demonetization and their intention to support the government policy to control black money are the major factors influencing the adoption of e-banking behavior (Table 5). Selfcontribution to the cashless economy and shortage of liquid cash are other factors causing the change in their banking behavior, especially when they are making their purchases or they are yielding to use Paytm. Student's ttest procedure provides overwhelming statistical evidence for the significance of these factors in sharpening the behavior of people to adopt e-banking services during the post demonetization phase in Telangana.

\section{CONCLUSION}

This research has investigated the e-banking behavior of people in Telangana during the pre and post demonetization phase. The Survey 200 bank customers in India indicated that the people have not inclined much to adopt e-banking system in their daily transactions. The study reveals that there is no much growth that occurred in the e-banking sector in Telangana through the demonetization policy of the Government. Moreover, the people in Telangana strongly believe that the demonetization policy of the Government is not much effective in curbing black money. Similarly, the study finds that demonetization has failed to make our economy a cashless one. Most of the people have been using e-banking services for cash withdrawal. However, demonetization brought cash withdrawal most difficult because of a shortage of cash and non-availability of currencies in needed denominations. The usage of debit cards, credit cards, smart cards, rupay cards, electronic fund transfer, and immediate payment service have declined considerably after the implementation of the demonetization policy. People have increased the usage of mobile banking services by 3 percent after demonetization. Paytm is the e-banking service that has received a magnificent increase of more than 70 percent in usage after demonetization. The usage of Point of Sale machines for making payments has increased tremendously. Even though the peoples' perception of the effectiveness of demonetization is negative they have partially inclined to the adoption of e-banking products in their lives. Better awareness of e-banking services during the times of demonetization and their intention to support the government policy to control black money are the major factors influencing the adoption of e-banking behavior.

Public awareness and literacy programs on the usefulness of e-banking products in transactions should be conducted at periodical intervals to increase the use of the e-banking system. More incentives should be offered to the customers for encouraging them to adopt cashless payment modes. There is a move from the part of the banks in India to hike minimum balances in bank accounts and the charges that the customers have to pay for using ATM and for making Electronic Fund Transfer. Such action pulls down the people from the adoption of e- banking behavior and hinders the Government's target to have a cashless economy. 
The demonetization policy of the Government had made a cash crunch in India. This cash crunch has said to be a boon for the e-banking sector. However, the findings of this research conducted reveal that no much growth in the e-banking sector has occurred, and a digital economy has not formed specifically in Telangana. Even though demonetization had not brought a growth in the e-banking sector, it had made an effect on this sector in the means that both incremental and decremental Even though the peoples' perception of the effectiveness of demonetization is negative they have partially inclined to the adoption of e-banking products in their lives. Here also, Likert type scaling measures their opinion as to the reasons why they adopt e-banking services in their daily lives. Mean score analysis revealed that better awareness of e-banking services during the times of demonetization and their intention to support the government policy to control black money are the major factors influencing the adoption of e-banking behavior (Table 5). Self-contribution to the cashless economy and shortage of liquid cash are other factors causing the change in their banking behavior, especially when they are making their purchases or they are yielding to use Paytm. Student's t-test procedure provides overwhelming statistical evidence for the significance of these factors in sharpening the behavior of people to adopt e-banking services during the post demonetization phase in Telangana.

\section{SOURCES OF FUNDING}

None.

\section{CONFLICT OF INTEREST}

None.

\section{ACKNOWLEDGMENT}

None.

\section{REFERENCES}

[1] S. Abbasi, S. Kamran and C.S. Akhtar. Factors Affecting Customers' Adoption of Internet Banking in Pakistan. Pakistan Administrative Review, Vol. 1, No. 2, pp.115-129, 1998.

[2] D.M. Amato-McCoy, D.M. Creating virtual value', Bank Systems and Technology, Vol.42, No.5, pp. 22-27, 2005.

[3] K.Dandapani, K., G.V. Karels, and E.R. Lawrence. Internet banking services and credit union performance. Managerial Finance, Vol. 34, No. 6, pp.437-447, 2008.

[4] S. Dhir. Banking on Innovation: Technological Innovations at ICICI Bank. AGBA Conference, 2014.

[5] A.M. Hyde, E-Banking: Review of literature. Prestige e-Journal of Management and Research, Vol.2, No.2, pp.19-28, 2015.

[6] H.Jenkins, Adopting internet banking services in a small island state: assurance of bank service quality. Managing Service Quality, Vol.17, No.5, pp.523-534, 2007.

[7] G.Kaur. Threats to the Rights of Consumers in E-Banking in India: An Overview. Available at SSRN: https://ssrn.com/abstract=2983199 or http://dx.doi.org/10.2139/ssrn.2983199

[8] B. Mwiya, F. Chikumbi, C. Shikaputo, C. Kabala., B. Kaulung'ombe, and B. Siachinji, Examining Factors Influencing E-Banking Adoption: Evidence from Bank Customers in Zambia. American Journal of Industrial and Business Management, Vo.7, pp.741-759, 2017. http://www.scirp.org/journal/ajibm

[9] G.R. Rao, and K. Prathima, Internet Banking in India. Mondaq Business Briefing, April 11, 2003.

[10] J. Reibstein, What attracts customers to online stores, and what keeps them coming back?. Academy of Marketing Science Journal, Vol.30, No.4, pp.465-474, 2002.

[11] I.P. Singh and P. Bassi. A Review on customer satisfaction with Internet Banking in Public and Private Bank. International Journal of Engineering Sciences \& Research Technology, Vol.6, No.1,pp. 448-452, 2017.

[12] S.Srikrishnan, S. Demonetization, the Movement to an Electronic Payments System and the inch towards Full Financial Inclusion in the Indian Economy. Senior Projects Spring 2017.276. http://digitalcommons.bard.edu/senproj_s2017/276 


\section{Dr. Itikela Shyam Sundar}

[13] L. Litvack, L., and S. Vigne. Demonetisation in India and Emerging Challenges: A Report Delivered to the Department for the Economy, Northern Ireland and the Government of India by Queen's University Belfast and O.P. Jindal Global University. Belfast: Queen's University Belfast, 2017.

[14] P.D. Witman, and T.L.Poust, Balances and accounts of online banking users: a study of two US financial institutions. International Journal of Electronic Finance, Vol.2, No.2, pp.197-210, 2008

[15] M.Zafar, A. Zaheer, and K. ur Rehman. Impact of online service quality on customer satisfaction in banking sector of Pakistan. African Journal of Business Management, Vol.5, No.30, pp.11786-11793, 2011.

[16] ess Control (MAC) and Physical Layer (PHY) Specification, IEEE Std. 802.11, 1997. 